\title{
Promising Immuno-Oncology Treatments Beyond the 2018 Nobel Prize
}

\section{Tratamentos Promissores de Imuno-Oncologia Para Além do Prémio Nobel 2018}

\author{
Luís CASTELO-BRANCO $\rrbracket^{* 1,2}$, Inês Pires SILVA*3, Helena CANHÃO2,4,5, Ahmad AWADA ${ }^{6}$
}

Acta Med Port 2019 Apr;32(4):251-257 • https://doi.org/10.20344/amp.12040

Keywords: Immunotherapy; Medical Oncology; Neoplasms/drug therapy; Neoplasms/immunology; Programmed Cell Death 1 Receptor Palavras-chave: Imunoterapia; Neoplasias/imunologia; Neoplasias/quimioterapia; Oncologia; Receptor de Morte Celular Programada 1

\section{IMMUNE-CHECKPOINT INHIBITORS: CLINICAL EVI- DENCE AND LIMITATIONS}

The Nobel Prize of Medicine in 2018 awarded jointly by James P. Allison and Tasuku Honjo was an important landmark recognizing recent clinical advances in immuneoncology. Targeting the immune system to fight cancer is not a new concept, but there were few significant clinical advances until very recently.

Tasuku Honjo et al first reported programmed cell death protein 1 (PD-1) in 1992, a protein expressed on the surface of T-cells that acts as a brake in T-cells cytotoxicity. ${ }^{1}$ So blocking PD-1 could facilitate T-cells activity against cancer.

In 1996 James P. Allison et al discovered that the cytotoxic T-lymphocyte-associated antigen 4 (CTLA-4) is a regulator of $\mathrm{T}$-cells activity, transmitting signals that inhibits its activation and proliferation, ${ }^{2}$ thus, blocking CTLA4 could improve T-cells activity against cancer.

These concepts were further explored with immune checkpoint inhibitors (ICl) anti-PD-1 and anti-CTLA-4, against cancer. Compared with classic chemotherapy, checkpoint inhibitors might take more time to be effective, but those who benefit are normally long-term responders (Fig. 1). The toxicity profile is globally more favorable compared with chemotherapy, with immune related adverse events being the major toxicity of concern but that is usually manageable with immune-modulators such as steroids and/ or treatment interruption.

Immune checkpoint inhibitors changed the panorama of metastatic melanoma dramatically, from a terrible prognosis and no efficacious treatment to $34 \%$ to $58 \%$ long term survivals. ${ }^{3,4}$

Further studies confirmed the benefit of checkpoint inhibitors across different types of cancers such as in lung, bladder, kidney, Merkel cell carcinoma, head and neck, lym- phomas among others. Results are not so impressive like in metastatic melanoma, but it is still very positive to change the gold standard of treatment of those diseases in some settings.

Moreover, the combination between different checkpoint inhibitors could improve clinical outcomes. In checkmate 067 clinical trial, in advanced melanoma patients, the overall survival rate at three years was $58 \%$ for nivolumab (anti-PD-1) plus ipilimumab (anti-CTLA-4) group, 52\% in the nivolumab group and $34 \%$ in the ipilimumab group. ${ }^{3}$ In advanced renal cell carcinoma, the overall survival and objective response rates were significantly higher with nivolumab plus ipilimumab vs sunitinib, which was the previous standard of care in this setting ${ }^{5}$ (Table 1).

Despite the achieved clinical results so far, the majority of patients treated do not benefit from immune checkpoint inhibitors, and there is still lack of evidence on predictors of (non) benefit. Therefore, it is very important to find more strategies to improve immune-oncology results, combining treatments with checkpoint inhibitors or developing other novel immune-oncology strategies (Fig. 2).

\section{NOVEL IMMUNE-ONCOLOGY STRATEGIES}

"Next-generation" immune checkpoints and co-stimulatory monoclonal antibodies

Three signals are needed for T-cell activation. The first signal happens when antigen-presenting cells (APCs) present the antigen through $\mathrm{MHC}$ to $\mathrm{T}$ cell receptor (TCR) on $T$ cells. The second signal occurs with the interaction between co-stimulatory receptors on $\mathrm{T}$ cells and their respective signals on APCs. Finally, the third signal comes from cytokines. Co-inhibitory (immune checkpoints) and co-stimulatory receptors are key for signal two, and their balance will determine T-cell activation. ${ }^{6}$

\footnotetext{
${ }^{*}$ Co-primeiros autores.

1. Serviço de Oncologia Médica. Centro Hospitalar e Universitário do Algarve. Faro. Portugal.

2. Departamento de Epidemiologia. Escola Nacional de Saúde Pública. Universidade NOVA de Lisboa. Lisboa. Portugal.

3. Melanoma Institute Australia. Sydney. Australia.

4. Centro de Estudos de Doenças Crónicas/ Chronic Diseases Research Center - CEDOC. Epidemiology of Chronic Diseases Unit - EpiDoC. NOVA Medical School. Universidade NOVA de Lisboa. Lisboa. Portugal.

5. Serviço de Reumatologia. Hospital Curry Cabral. Centro Hospitalar e Universitário de Lisboa Central. Lisboa. Portugal.

6. Medical Oncology Institut Jules Bordet. Université Libre de Bruxelles. Brussels. Belgium.

$\triangle$ Autor correspondente: Luís Castelo-Branco. luismocb@hotmail.com

Recebido: 10 de março de 2019 - Aceite: 20 de março de 2019| Copyright @ Ordem dos Médicos 2019
} 


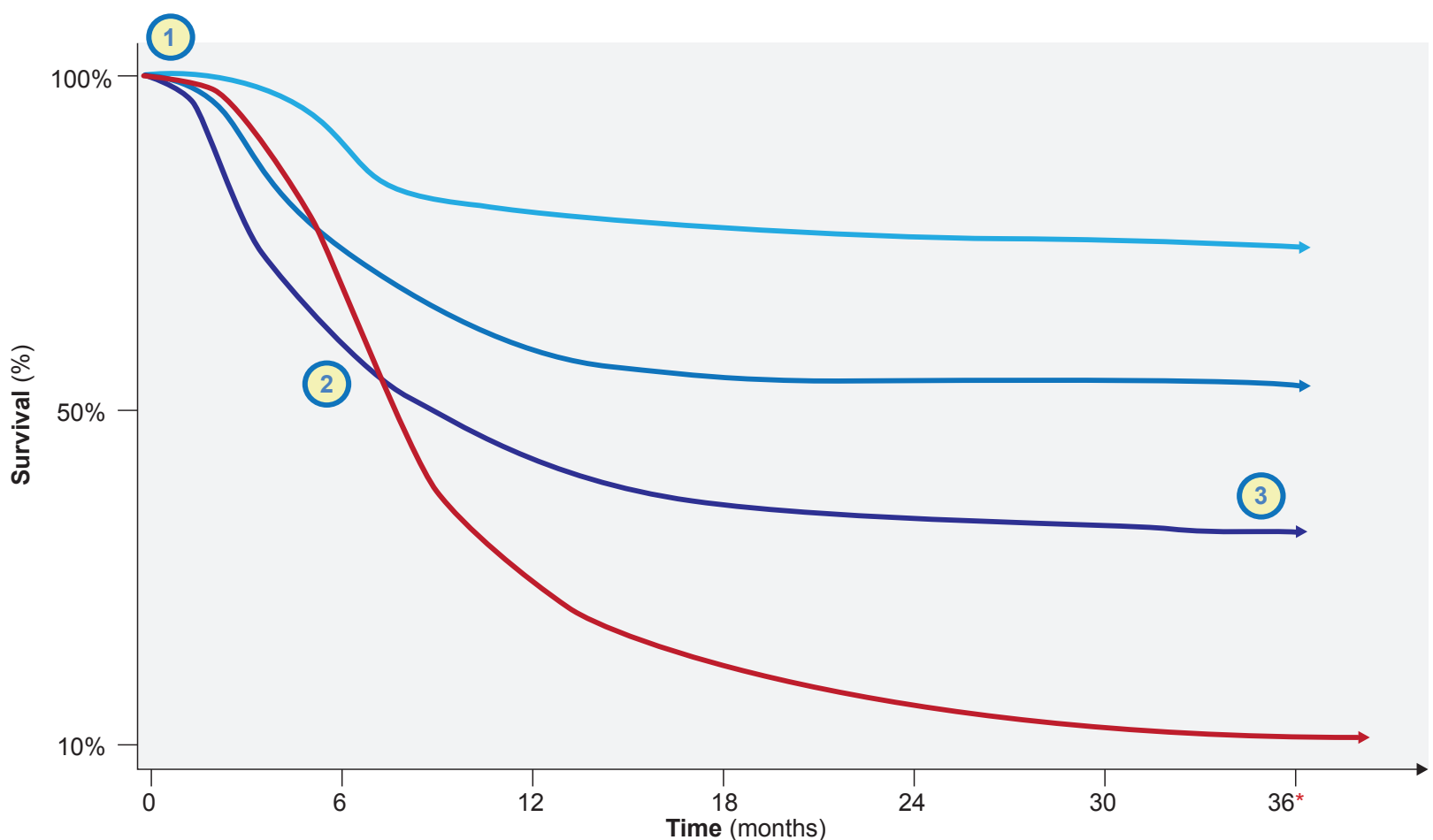

Combination or sequence plus predictors of response

Checkpoint inhibitors monotherapy

Figure 1 - Survival: curve with immune checkpoint inhibitors

1 - Later response with $\mathrm{ICI}$ - Chemotherapy has a rapid cytotoxicity and tumor reduction effect. ICI monotherapy requires some weeks to months to start having effect; 2 - Median is a bad outcome: Median OS or PFS are current outcomes used in oncology clinical trials, but due to the delay but long term effect with $\mathrm{ICl}$, it is important to find other outcomes which better capture the magnitude of benefit with ICls; 3 - Long term responders: Those who benefit from ICls are normally long term responders, having a chronic disease or perhaps being cured

* Ilustrative time. Time changes with different types of cancer.

The co-inhibitory receptors, CTLA-4 and PD-1, have been described to be responsible for maintaining overall immune self-tolerance, while "next-generation" immune checkpoints, including T-cell immunoglobulin and mucindomain containling-3 (Tim-3), lymphocyte activation gene3 (Lag-3) and T-cell immunoreceptor with Ig and ITIM domains (TIGIT), have more specific roles in tolerance. These three co-inhibitory receptors are highly expressed on the dysfunctional and exhausted T cells and NK cells. ${ }^{7,8}$ Preclinical data have shown anti-tumor activity of monoclonal antibodies against these receptors, ${ }^{9-11}$ and now these drugs are currently being studied in clinical trials for hematologic and solid tumors, either alone (NCT03489369; NCT03489343; NCT01968109), or in combination with anti-CTLA-4 and/or anti-PD-1 therapy (Table 1).

Co-stimulatory receptors, including 4-1BB, glucocorticoid-induced TNFR-related protein (GITR) and OX40 promote $T$ cells survival, activation and proliferation. Studies performed in different pre-clinical models using agonistic monoclonal antibodies targeting these receptors in combination with anti-PD-1 have shown non-consistent results. ${ }^{12,13}$ While more work needs to be done in this field to better understand the mechanism of action of these antibodies, the first clinical trials using these agents, alone or in combination with anti-CTLA-4 and/or anti-PD-1, in cancer patients are ongoing and their results are awaited (NCT01239134; NCT03126110; NCT03241173).

\section{Adoptive cell therapy}

Adoptive cell therapy (ACT) uses tumor-infiltrating lymphocytes (TILs) extracted from fresh tumor samples, or peripheral blood lymphocytes (leukapheresis). After extracting these lymphocytes, there is a selection of the ones expressing T cell receptor (TCR) targeting a specific tumor antigen, or they can be genetically engineered to express the desired TCR. These lymphocytes are expanded and activated ex vivo, and then infused into the patients, after lymphodepletion to eliminate regulatory $\mathrm{T}$ cells..$^{14,15}$

In a National Cancer Institute $(\mathrm{NCl})$ clinical trial, metastatic melanoma patients were previously subjected to total body irradiation (TBI - 2 Gy or 12Gy) and to a non-myeloablative regimen with fludarabine and cyclophosphamide, while the cells were expanded with the T-cell stimulating anti-CD3 monoclonal antibody (OKT3) and IL-2. In this study, objective responses were observed in $49 \%$ to $72 \%$ depending on the conditioning regimen prior to the cells' infusion. 
Even though these results are promising, this was a single arm trial with no randomized comparison. ${ }^{16}$ Moreover, there are some obstacles to this technique that need to be addressed in order to increase its efficacy, including the im- munosuppressive tumor microenvironment and the lack of automation in the ACT production process, as it is a highly personalized treatment, is labor-intensive and requires laboratory expertise. ${ }^{15}$ This strategy is now being tested in

Table 1 - Selection of clinical trials with Immune checkpoint inhibitors combinations

\begin{tabular}{|c|c|c|c|c|c|}
\hline Combination & Tumour type & Cohorts & $\begin{array}{l}\text { Outcome } \\
\text { (mPFS) }\end{array}$ & Clinical Trial & Reference \\
\hline \multirow[t]{3}{*}{$\mathrm{ICI}+\mathrm{ICI}$} & $\begin{array}{l}\text { Advanced } \\
\text { melanoma } \\
\left(1^{\text {st }} \text { line }\right)\end{array}$ & $\begin{array}{l}\text { Ipilimumab } \\
\text { Nivolumab } \\
\text { Ipilimumab + Nivolumab }\end{array}$ & $\begin{array}{l}2.9 \mathrm{mo} \\
6.9 \mathrm{mo} \\
11.5 \mathrm{mo}\end{array}$ & $\begin{array}{l}\text { Checkmate-067 } \\
\text { Phase } 3\end{array}$ & Wolchok JD, 2017 \\
\hline & $\begin{array}{l}\text { Advanced } \\
\mathrm{RCC} \\
\left(1^{\text {st }} \text { line }\right)\end{array}$ & $\begin{array}{l}\text { Sunitinib } \\
\text { Ipilimumab + Nivolumab }\end{array}$ & $\begin{array}{l}8.4 \mathrm{mo} \\
11.6 \mathrm{mo}\end{array}$ & $\begin{array}{l}\text { Checkmate-214 } \\
\text { Phase } 3\end{array}$ & Motzer RJ, 2018 \\
\hline & $\begin{array}{l}\text { Solid tumors } \\
\left(>1^{\text {st }} \text { line }\right)\end{array}$ & $\begin{array}{l}\text { Relatlimab* } \\
\text { Relatlimab + Nivolumab }\end{array}$ & Recruiting & Phase $1 / 2$ & NCT01968109 \\
\hline \multirow[t]{2}{*}{$\begin{array}{l}\mathrm{ICI}+ \\
\text { Costimulatory } \\
\text { agonist }\end{array}$} & $\begin{array}{l}\text { Gastric cancer, } \\
\text { SCCHN, NSCLC } \\
\text { or advanced RCC }\end{array}$ & $\begin{array}{l}\text { INCAGN01876§ + Nivolumab } \\
\text { INCAGN01876 + Ipilimumab } \\
\text { INCAGN01876 + Nivolumab + Ipilimumab }\end{array}$ & Recruiting & Phase 1/2 & NCT03126110 \\
\hline & $\begin{array}{l}\text { Refractory to prior } \\
\text { PD-1/L1 therapy }\end{array}$ & $\begin{array}{l}\text { INCAGN01949§§ + Nivolumab } \\
\text { INCAGN01949 + Ipilimumab } \\
\text { INCAGN01949 + Nivolumab + Ipilimumab }\end{array}$ & Recruiting & Phase 1/2 & NCT03241173 \\
\hline $\begin{array}{l}\mathrm{ICI}+\text { Adoptive } \\
\text { cell therapy }\end{array}$ & $\begin{array}{l}\text { Advanced } \\
\text { melanoma } \\
\text { (any line) }\end{array}$ & Adoptive cell transfer + Ipilimumab & $\begin{array}{l}\text { Active, not } \\
\text { recruiting }\end{array}$ & Phase 2 & NCT02027935 \\
\hline \multirow[t]{2}{*}{$\mathrm{ICI}+$ Vaccines } & $\begin{array}{l}\text { Advanced } \\
\text { pancreatic cancer } \\
\text { (any line \& no } \\
\text { previous PD1 or } \\
\text { CTLA4 treatment) }\end{array}$ & $\begin{array}{l}\text { Nivolumab + Ipilimumab } \\
\text { Nivolumab + Ipilimumab + } \\
\text { GVAX } ¥ \text { Pancreas vaccine }\end{array}$ & Recruiting & Phase 2 & NCT03190265 \\
\hline & $\begin{array}{l}\text { HPV-16-Positive } \\
\text { incurable } \\
\text { solid tumors }\end{array}$ & Nivolumab + ISA $101 \pi$ & $\begin{array}{l}\text { Active, not } \\
\text { recruiting }\end{array}$ & Phase 2 & NCT02426892 \\
\hline $\begin{array}{l}\mathrm{ICI}+\text { Oncolytic } \\
\text { Virus }\end{array}$ & $\begin{array}{l}\text { Advanced } \\
\text { melanoma } \\
\text { ( } 1^{\text {st }} \text { line of previous } \\
\text { BRAFi/MEKi) }\end{array}$ & Pembrolizumab + TVEC & $\begin{array}{l}\text { Active, not } \\
\text { recruiting }\end{array}$ & Keynote-034 Phase 3 & NCT02263508 \\
\hline \multirow[t]{2}{*}{$\begin{array}{l}\mathrm{ICI}+ \\
\text { Radiotherapy }\end{array}$} & $\begin{array}{l}\text { NSCLC } \\
\text { locally advanced, } \\
\text { unresectable }\end{array}$ & $\begin{array}{l}\text { Chemoradiotherapy + Durvalumab } \\
\text { Chemoradiotherapy + Placebo }\end{array}$ & $\begin{array}{l}16.8 \mathrm{mo} \\
5.6 \mathrm{mo}\end{array}$ & $\begin{array}{l}\text { PACIFIC } \\
\text { Phase } 3\end{array}$ & Antonia SJ, 2017 \\
\hline & $\begin{array}{l}\text { SCCHN } \\
\text { locally advanced }\end{array}$ & $\begin{array}{l}\text { Pembrolizumab + Radiotherapy } \\
\text { Cetuximab + Radiotherapy }\end{array}$ & $\begin{array}{l}\text { Active, not } \\
\text { recruting }\end{array}$ & Phase 2 & NCT02707588 \\
\hline \multirow[t]{2}{*}{$\begin{array}{l}\mathrm{ICl}+ \\
\text { Chemotherapy }\end{array}$} & $\begin{array}{l}\text { NSCLC } \\
\text { nonsquamous } \\
\text { metastatic } \\
\left(1^{\text {st }} \text { line }\right)\end{array}$ & $\begin{array}{l}\text { Chemotherapy + Pembrolizumab } \\
\text { Chemotherapy + Placebo }\end{array}$ & $\begin{array}{l}8.8 \mathrm{mo} \\
4.9 \mathrm{mo}\end{array}$ & $\begin{array}{l}\text { KEYNOTE } 189 \\
\text { Phase } 3\end{array}$ & Gandhi L, 2018 \\
\hline & $\begin{array}{l}\text { TNBC } \\
\text { metastatic }\end{array}$ & $\begin{array}{l}\text { Nab-paclitaxel + Atezolizumab } \\
\text { Nab-paclitaxel + Placebo }\end{array}$ & $\begin{array}{l}7.2 \mathrm{mo} \\
5.5 \mathrm{mo}\end{array}$ & IMpassion130 Phase 3 & Schmid P, 2018 \\
\hline \multirow[t]{2}{*}{$\begin{array}{l}\mathrm{ICI}+\text { small } \\
\text { molecules }\end{array}$} & Advanced RCC & $\begin{array}{l}\text { Axetinib + Avelumab } \\
\text { Sunitinib }\end{array}$ & $\begin{array}{l}13.8 \mathrm{mo} \\
8.4 \mathrm{mo}\end{array}$ & $\begin{array}{l}\text { JAVELIN renal } 101 \\
\text { Phase } 3\end{array}$ & Motzer RJ, 2018 \\
\hline & $\begin{array}{l}\text { NSCLC } \\
\text { locally advanced } \\
\text { or metastatic }\end{array}$ & $\begin{array}{l}\text { Avelumab + Crizotinib } \\
\text { Avelumab + PF-06463922 } \pi \pi\end{array}$ & $\begin{array}{l}\text { Active, not } \\
\text { recruiting }\end{array}$ & $\begin{array}{l}\text { Javelin Lung } 101 \\
\text { Phase } 2\end{array}$ & NCT02584634 \\
\hline
\end{tabular}

mPFS: median progression free survival in months; ICl: immune checkpoint inhibitors; mo: months; SCCHN: squamous cell carcinoma of head and neck; NSCLC: non small cell lung cancer; RCC: renal cell carcinoma; TNBC: triple negative breast cancer; TVEC: talimogene Laherparepvec (oncolytic herpes virus);

* Relatlimab - anti-LAG-3; § INCAGN01876 - anti-human glucocorticoid-induced tumor necrosis factor receptor (GITR) agonistic humanized monoclonal antibody; ${ }^{\S}$ INCAGN01949 anti-human OX-40 agonistic monoclonal antibody; ${ }^{\ddagger}$ GVAX- cancer vaccine; $\pi$ ISA101 - HPV-16 vaccination; 1 ा PF-06463922 - dual ALK/ROS1 inhibitor 
A Next generation

Immune-checkpoint modulators

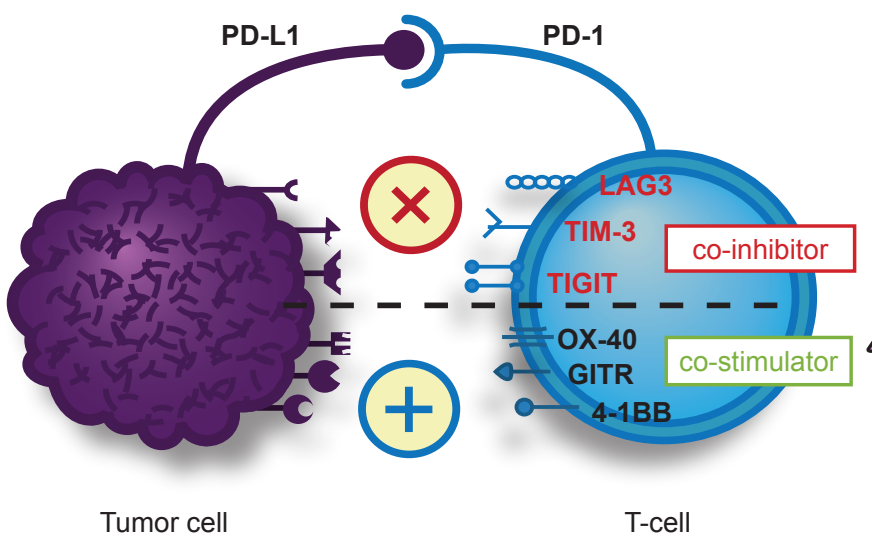

C Vaccines

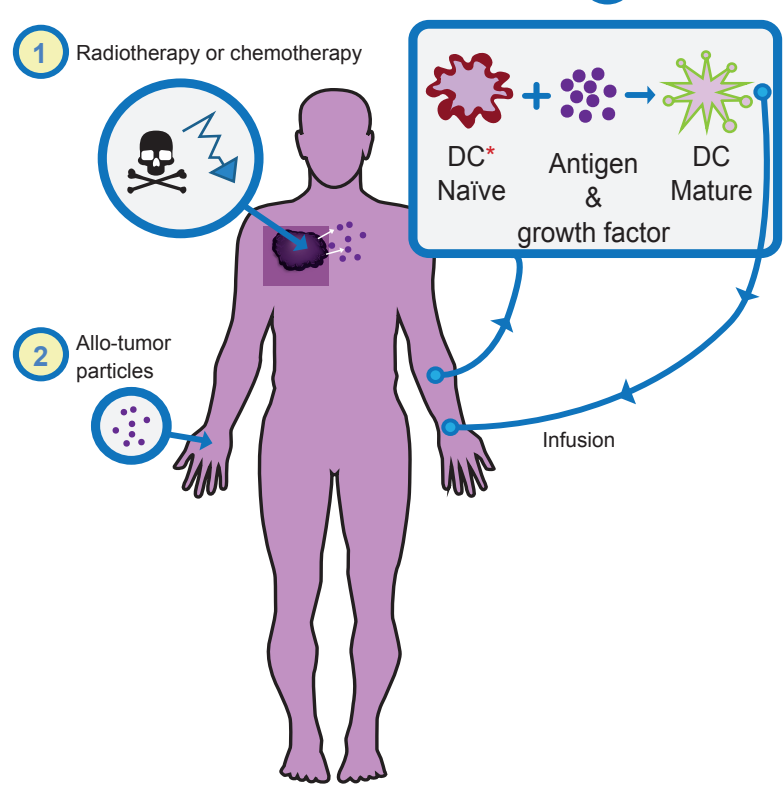

\section{Adoptative cell therapy}

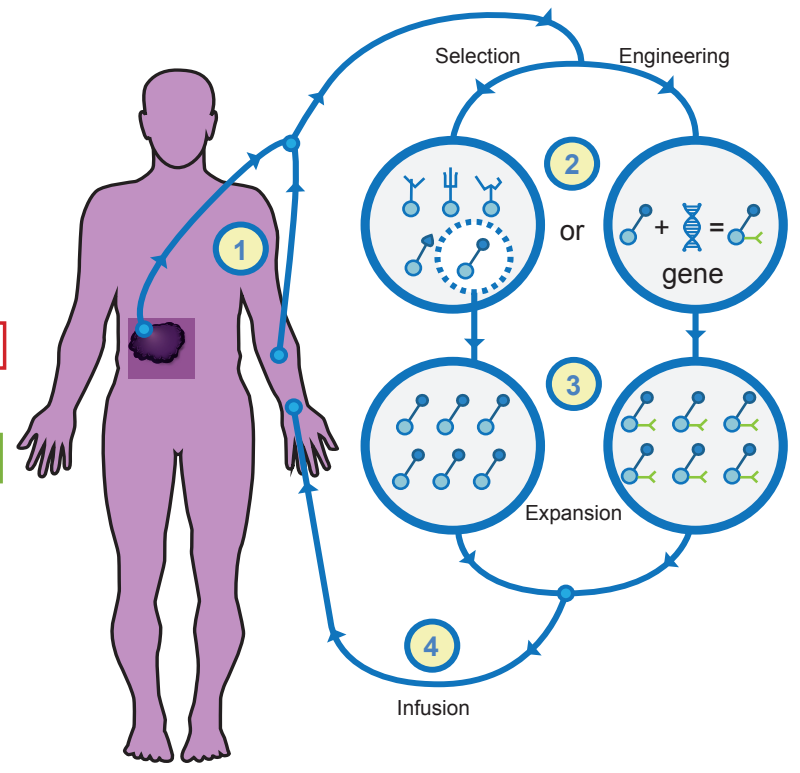

(D) Oncolytic virus

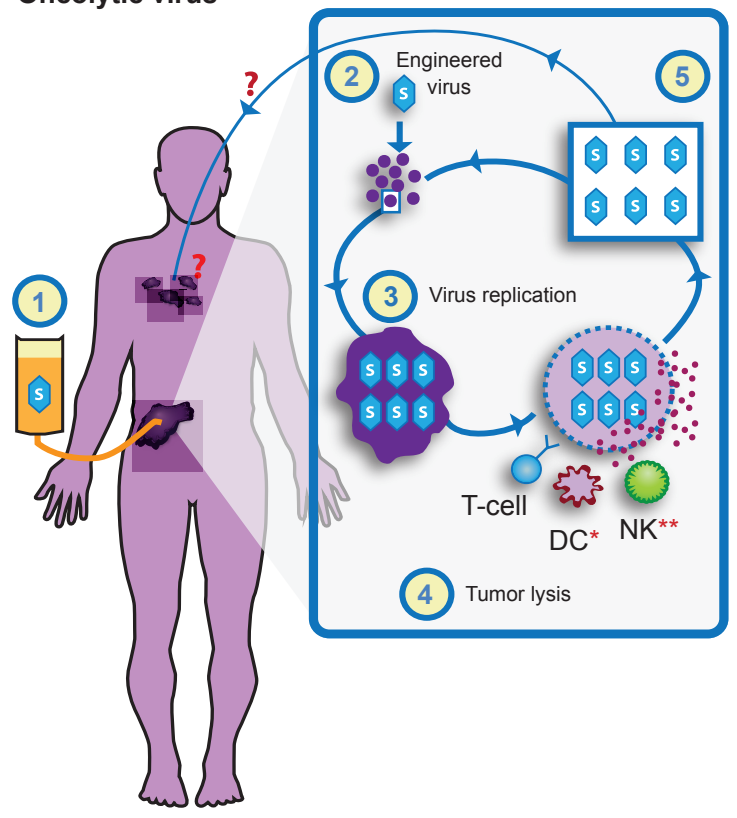

Figure 2 - Novel immune-oncology strategies

(A) 'Next-generation' immune checkpoint modulators: After positive results with anti-pd1 or anti pd-l1 drugs, blocking other checkpoint inhibitors (eg. LAG-3, TIM-3, TIGIT), or activate co-stimulators (eg.OX-40, 4-1BB, GITR) are promising immune-oncology strategies on clinical research.

(B) Adoptive cell therapy. 1 - Extraction of tumor-infiltrating lymphocytes (TILs) or lymphocytes from peripheral blood; 2 - Selection of TILs targeting a specific tumor antigen, or engineering of lymphocytes to express a desired antigen receptor - Chimeric antigen receptor $\mathrm{T}$ cells (CAR T cells); 3 - Expansion of T cells; 4 - Infusion of T-Cells for a specific immune-reaction against cancer.

(C) Vaccines: 1 - Cytotoxic treatments (e.g. chemotherapy or radiotherapy) can induce tumor lysis and antigens release to be recognized by immune-system; 2 - Some tumor particles (proteins or glucosides), when injected on a tumor-naive patient, might induce immunization against those tumors, and combination with immune-stimulator agents could improve such benefit; 3 - Dendritic cells are collected, exposed ex-vivo to tumor antigens and growth factors to become mature and further infused to induce immunization against cancer.

(D) Oncolytic virus: 1 - Local administration of oncolytic virus on tumor site; 2 - Selective infection of tumor cells by oncolytic virus (e.g. T-VEC in melanoma); 3 - Replication of virus inside tumor cells; 4 - Tumor lysis and antigen release. Immune system (innate and adaptative) could more easily recognize tumor antigens; 5 - Oncolytic virus could infect more local tumor cells, but the benefit on distant lesions it is still unknown and remains a challenge.

$\mathrm{DC}^{*}$ : dendritic cells; $\mathrm{NK}^{* *}$ : natural killers 
combination with ipilimumab in a phase II trial for advanced melanoma patients (Table 1).

Adoptive transfer of $\mathrm{T}$ cells engineered with TCRs or chimeric antigen receptors (CARs) is a strategy to improve the efficacy of the anti-tumor response. The TCR therapy consists of the isolation of normal circulating T-cells from the patient's blood and genetically modified via transfection. CARs, which consist of the combination of an antibody and a TCR, are antigen specific and their activation is not dependent on MHC expression on tumor cells. CAR-T cells therapy has been particularly successful in hematologic cancers, including the CTL019 for young adult B-ALL patients $^{17}$ (Grupp, 2016) and the CT019 for refractory aggressive NHL. ${ }^{18}$

\section{Vaccines}

The goal of cancer vaccination is to induce an efficient antigen presentation generating an anti-tumor response, based on CD4+ and CD8+ $\mathrm{T}$ lymphocytes against tumorspecific antigens, that is sufficiently robust to be able to produce long-lasting clinical responses. Different strategies have been studied including: (1) non-targeted vaccines, using non-specific strategies to induce an immunogenic tumor cell death, including radiotherapy, some chemotherapies or administration of tumor specific antigens to induce immunization against tumor; (2) ex vivo generated dendritic cells (DCs), including activation, expansion and reinfusion of DCs into the patient; (3) in vivo DC targeting..$^{19}$

Sipuleucel-T is the only cancer vaccine approved by the FDA. This vaccine consists of autologous peripheral blood mononuclear cells (PBMC) obtained by leukapheresis and cultured with the fusion protein that combines recombinant PAP with recombinant granulocyte-macrophage colonystimulating factor (GM-CSF). In a phase III trial (Impact trial), 512 men with metastatic castration-resistant prostate cancer were randomly assigned to receive either the vaccine Sipuleucel-T or placebo. This trial showed a relative reduction of $22 \%$ in the risk of death in the Sipuleucel-T group as compared with the placebo group (hazard ratio, $0.78 ; 95 \%$ confidence interval [Cl], 0.61 to $0.98 ; p=0.03) .{ }^{20}$ Different types of vaccines are now being tested in combination with anti-CTLA-4 and/or anti-PD-1 for different tumor types (Table 1).

\section{Oncolytic virus}

Oncolytic viruses, like vaccines, stimulate antigen presentation and generate an anti-tumor response. Oncolytic viruses infect/invade, replicate within and kill tumor cells, inducing antigen release and promoting a pro-inflammatory environment. The only FDA approved oncolytic virus is the T-VEC (talimogenelaherparepvec), consisting of attenuated herpes simplex virus (HSV) associated with GM-CSF. TVEC was studied in a phase III trial (2:1) with 436 unresectable stage IIIA/B/C melanoma patients. The T-VEC or the GM-CSF alone were injected into the tumor, with an overall objective response of $26.4 \%$ and $5.7 \%$ for the arms of the T-VEC and GM-CSF, respectively. ${ }^{21}$ Even though the results seem compelling, in order to fully understand the effect of T-VEC, as well as other intralesional agents, it would be important to study the effect of these intralesional agents on the non-injectable lesions. T-VEC is now being studied alone or in different combinations, including immune checkpoints, radiotherapy and chemotherapy (NCT03086642; NCT02263508; NCT03554044). An important challenge ahead with oncolytic virus is to have a very selective infection on tumor cells, without their recognition/destruction by the immune-system, thus optimizing the clinical benefit also on distant metastasis, without major side-effects.

\section{Bifunctional agents}

This new immunotherapy strategy refers to bispecific antibodies that bind to two different antigens with high affinity. Bispecific T-cell engagers (BiTE's) are a particular type of bispecific antibodies that bind to CD3+ cells and to a tumor specific antigen. The first BiTE to be approved by the FDA was Blinatumomab for B-cell acute lymphoblastic leukemia (B-ALL). Blinatumomab binds to CD3, expressed by T cells, and to CD19, expressed by B cells. In a phase II trial, blinatumomab showed impressive clinical activity, inducing $43 \%$ complete responses in refractory B-ALL patients ${ }^{22}$. Some of the advantages of BiTE's include the cytotoxic capacity and the ability to bind to tumor cells expressing low antigen levels. ${ }^{23}$

\section{COMBINATION OF CHECKPOINT INHIBITORS WITH CLASSIC TREATMENTS}

There are different combinations between checkpoint inhibitors and other treatment strategies being tested (Table 1), and that includes combination with 'older' oncology treatments such as chemotherapy, radiotherapy or small molecules.

\section{Checkpoint inhibitors plus radiotherapy}

Different doses of ionizing radiation can have an immunosuppressive or immune-stimulator effect. ${ }^{24}$ Therefore, finding optimal schemes combining radiotherapy with checkpoint inhibitors is crucial to optimize this synergic benefit. Different clinical studies showed an increased response rate for patients receiving combination of radiotherapy with $\mathrm{ICl}$, with no significant increase in toxicity ${ }^{25-27}$ and there is a growing number of clinical trials addressing combination or sequence between radiotherapy and immunotherapy. The best combination or sequence of treatment, radiotherapy doses and fraction schedules across different tumor types, are still important challenges to be addressed.

\section{Checkpoint inhibitors with chemotherapy}

Chemotherapy is still the gold-standard in many oncology settings, and there is a strong interest to combine it with $\mathrm{ICl}$. Chemotherapy can have a myelosuppressive effect or stimulate the immune system by different mechanisms, ${ }^{28}$ depending on doses, type of chemotherapy, type of cancer, among other factors. Thus, it is very important to optimize these combination strategies to gain clinical 
benefit. In non-squamous, non-small-cell lung cancer, the addition of pembrolizumab to standard chemotherapy improved OS and PFS comparing with chemotherapy alone..$^{29}$ Also, in metastatic triple negative breast cancer, atezolizumab plus nab-paclitaxel increased the median PFS and mainly OS in PD-L1 positive immune cells infiltrating the tumor compared with nab-paclitaxel plus placebo. ${ }^{30}$ There are many ongoing clinical trials combining chemotherapy with checkpoint inhibitors and more positive results can be expected in a near future.

\section{Checkpoint inhibitors with small molecules}

Some small molecules, such as tyrosine kinase inhibitors (TKIs) can block important intracellular signaling pathways for tumor growth and survival. These drugs have been widely used across different tumor types, such as leukemia, lung, renal, breast cancers, among others. With these drugs a tumor response can be expected, but due to drug resistance clones there is also a high rate of relapse. There is a strong rationale to combine $\mathrm{TKI}$ s with $\mathrm{ICl}$, having the benefit of faster TKIs response and potentially long term responses with ICls. In advanced renal cell carcinoma, axitinib plus avelumab $(\mathrm{TKI}+\mathrm{ICl})$ significantly improved PFS versus the standard of care sunitinib, ${ }^{31}$ thus becoming a possible firstline treatment for this setting. There are many ongoing different trials combining TKIs plus ICls in different tumor settings and results are awaited (Table 1).

\section{FUTURE PERSPECTIVES}

Despite positive results achieved with immune check- point inhibitors, decreasing the number of non-responders and improving clinical results is still an important challenge ahead.

Finding reliable predictors of response is an important goal for the near future, and that can be very helpful to select those who might benefit and to identify those who will not respond to the available drugs.

Novel immune-oncology strategies and combination with other treatment strategies are showing promising results, and there is a strong rationale to expect more positive results in a near future.

Moreover, the identification of new mechanisms of resistance to $\mathrm{ICl}$ and new therapeutic targets makes it imperative to help this significant proportion of patients that do not benefit from available immunotherapy strategies.

Finally, a more personalized research, with the identification of more subgroups of disease (e.g., MSI positive solid tumors) can be helpful to select specific treatment strategies towards a tendentially more personalized immune-oncology medicine.

\section{ACKNOWLEDGEMENTS}

The authors would like to thank Rui Matos for producing the figures that illustrate the article.

\section{CONFLICTS OF INTEREST}

All authors report no conflict of interest.

\section{FUNDING SOURCES}

The authors received no financial support for this article

\section{REFERENCES}

1. Ishida YA, Agata Y, Shibahara K, Honjo T. Induced expression of PD1 , a novel member of the immunoglobulin gene superfamily, upon programmed cell death. EMBO J. 1992;11:3887-95.

2. Leach DR, Krummel MF, Allison JP. Enhancement of Antitumor Immunity by CTLA-4 Blockade. Science. 1996; 271:1734-6.

3. Wolchok JD, Chiarion-Sileni V, Gonzalez R, Rutkowski P, Grob JJ Cowey $\mathrm{CL}$, et al. Overall survival with combined nivolumab and ipilimumab in advanced melanoma. N Engl J Med. 2017;377:1345-56.

4. Schachter J, Ribas A, Long GV, Arance A, Grob JJ, Mortier L, et al. Pembrolizumab versus ipilimumab for advanced melanoma: final overall survival results of a multicentre, randomised, open-label phase 3 study (KEYNOTE-006). Lancet. 2017;390:1853-62.

5. Motzer RJ, Tannir NM, McDermott DF, Arén Frontera O, Melichar B, Choueiri TK, et al. Nivolumab plus ipilimumab versus sunitinib in advanced renal-cell carcinoma. N Engl J Med. 2018;378:1277-90.

6. Marshall HT, Djamgoz MB. Immuno-oncology: emerging targets and combination therapies. Front Oncol. 2018;8:315.

7. Wherry EJ, Kurachi M. Molecular and cellular insights into $T$ cell exhaustion. Nat Rev Immunol. 2015;15:486-99.

8. da Silva IP, Gallois A, Jimenez-Baranda S, Khan S, Anderson AC, Kuchroo VK, et al. Reversal of NK-cell exhaustion in advanced melanoma by Tim-3 blockade. Cancer Immunol Res. 2014;2:410-22.

9. Matsuzaki J, Gnjatic S, Mhawech-Fauceglia P, Beck A, Miller A, Tsuji T, et al. Tumor-infiltrating NY-ESO-1-specific CD8+ T cells are negatively regulated by LAG-3 and PD-1 in human ovarian cancer. Proc Natl Acad Sci U S A. 2010;107:7875-80.

10. Ngiow SF, Von Scheidt B, Akiba H, Yagita H, Teng MW, Smyth MJ. AntiTIM3 antibody promotes T cell IFN-gamma-mediated antitumor immunity and suppresses established tumors. Cancer Res. 2011;71:3540-51.

11. Johnston RJ, Comps-Agrar L, Hackney J, Yu X, Huseni M, Yang Y, et al. The immunoreceptor TIGIT regulates antitumor and antiviral CD8+T cell effector function. Cancer Cell. 2014;26:923-37.
12. Bartkowiak T, Curran MA. 4-1BB agonists: multi-potent potentiators of tumor immunity. Front Oncol. 2015;5:117.

13. McKee SJ, Doff BL, Soon MS, Mattarollo SR. Therapeutic efficacy of 4-1BB costimulation Is abrogated by PD-1 blockade in a model of spontaneous B-cell lymphoma. Cancer Immunol Res. 2017;5:191-7.

14. Baruch EN, Berg AL, Besser MJ, Schachter J, Markel G. Adoptive T cell therapy: an overview of obstacles and opportunities. Cancer. 2017;123:2154-62.

15. Rosenberg SA, Restifo NP, Yang JC, Morgan RA, Dudley ME. Adoptive cell transfer: a clinical path to effective cancer immunotherapy. Nat Rev Cancer. 2008;8:299-308.

16. Dudley ME, Yang JC, Sherry R, Hughes MS, Royal R, Kammula U, et al. Adoptive cell therapy for patients with metastatic melanoma: evaluation of intensive myeloablative chemoradiation preparative regimens. J Clin Oncol. 2008;26:5233-9.

17. Grupp SA, Laetsch TW, Buechner J, acrescentar mais três autores, et al. Analysis of a global registration trial of the efficacy and safety of CTL019 in pediatric and young adults with relapsed/refractory acute lymphoblastic leukemia (ALL). Blood. 2016;128:221.

18. Neelapu SS, Locke FL, Bartlett NL, Lekakis LJ, Miklos DB, Jacobson $\mathrm{CA}$, et al. Axicabtagene ciloleucel CAR T-cell therapy in refractory large B-cell lymphoma. N Engl J Med. 2017;377:2531-544.

19. Palucka K, Banchereau J. Dendritic-cell-based therapeutic cancer vaccines. Immunity. 2013;39:38-48.

20. Kantoff PW, Higano CS, Shore ND, Berger ER, Small EJ, Penson DF, et al. Sipuleucel-T immunotherapy for castration-resistant prostate cancer. N Engl J Med. 2010;363:411-22.

21. Andtbacka RH, Kaufman HL, Collichio F, Amatruda T, Senzer N, Chesney J, et al. Talimogene laherparepvec improves durable response rate in patients with advanced melanoma. J Clin Oncol. 2015;33:2780-8.

22. Topp MS, Gökbuget N, Stein AS, Zugmaier G, O'Brien S, Bargou RC, et al. Safety and activity of blinatumomab for adult patients with relapsed 
or refractory B-precursor acute lymphoblastic leukaemia: a multicentre, single-arm, phase 2 study. Lancet Oncol. 2015;16:57-66.

23. Kobold S, Pantelyushin S, Rataj F, Vom Berg J. Rationale for combining bispecific $T$ cell activating antibodies with checkpoint blockade for cancer therapy. Front Oncol. 2018;8:285.

24. Rodríguez-Ruiz ME, Vanpouille-Box C, Melero I, Formenti SC, Demaria S. Immunological mechanisms responsible for radiation-induced abscopal effect. Trends Immunol. 2018;39:644-55.

25. Thangamathesvaran L, Shah $R$, Verma $R$, Mahmoud O. Immune checkpoint inhibitors and radiotherapy-concept and review of current literature. Ann Transl Med. 2018;6:155.

26. Antonia SJ, Villegas A, Daniel D, Vicente D, Murakami S, Hui R, et al. Durvalumab after chemoradiotherapy in stage III non-small-cell lung cancer. N Engl J Med. 2017;377:1919-29.

27. Koller KM, Mackley HB, Liu J, Wagner H, Talamo G, Schell TD, et al. Improved survival and complete response rates in patients with advanced melanoma treated with concurrent ipilimumab and radiotherapy versus ipilimumab alone. Cancer Biol Ther. 2017;18:36-42.

28. Yan $Y$, Kumar AB, Finnes $H$, Markovic SN, Park S, Dronca RS, et al. Combining immune checkpoint inhibitors with conventional cancer therapy. Front Immunol. 2018;9:1739.

29. Gandhi L, Rodríguez-Abreu D, Gadgeel S, Esteban E, Felip E, De Angelis F. Pembrolizumab plus chemotherapy in metastatic non-smallcell lung cancer. N Engl J Med. 2018;378:2078-92.

30. Schmid P, Adams S, Rugo HS, Schneeweiss A, Barrios $\mathrm{CH}$, Iwata $\mathrm{H}$, et al. Atezolizumab and nab-paclitaxel in advanced triple-negative breast cancer. N Engl J Med. 2018;379:2108-21.

31. Motzer RJ, Penkov K, Haanen J, Rini BI, Albiges L, Campbell MT, et al. LBA6_PR JAVELIN renal 101: a randomized, phase III study of avelumab + axitinib vs sunitinib as first-line treatment of advanced renal cell carcinoma (aRCC). Ann Oncol. 2018;29:mdy424.036. 